\title{
Impact of weather on dynamics of plant functional groups in an abandoned limestone grassland
}

\author{
Zbigniew Dzwonko*, Stefania Loster \\ Institute of Botany, Jagellonian University, Lubicz 46, 31-512 Kraków, Poland
}

\section{Abstract}

We examined to what extend the rate and direction of changes in unmanaged grassland depend on fluctuations in climatic conditions. Vegetation data from permanent plots in a semi-natural grassland in southern Poland collected over 12 years were used. Relations between weather variables, time, and the cover of 41 more frequent species and 14 plant functional groups were analysed. The greatest effect on the dynamics of species and functional groups had precipitation in spring and/or early summer, particularly in the current year. The majority of plant groups were significantly affected also by the temperature in spring and early summer in one of the three previous years. During 12 years, the cover of annuals and biennials, short plants, and plants with small leaves decreased, while the cover of taller plants, plants with larger leaves, and with vegetative spread increased. The analyses suggest that these successional changes were not directly associated with climatic conditions but were affected by them indirectly through interspecific competition. The fluctuations in climatic conditions, chiefly precipitation, had a significant effect on both the composition and the rate of changes in abandoned grassland. The increase in the cover of tall perennial species with broad leaves hindered succession towards woodland despite of the presence of woods in the closed vicinity. It can be expected that during drier periods colonisation of grassland by later successional species could be easier.

Keywords: permanent plots, plant functional groups, plant-weather relations, secondary succession, southern Poland, time series

\section{Introduction}

Abandoned limestone grasslands are characteristic elements of the agricultural landscape in the hilly regions of southern Poland. Like in other parts of Europe these remnants of seminatural grasslands are the refuges for many grassland and xerothermic species of plants and small animals. Therefore maintaining such grassland communities is of utmost importance to the conservation of local and regional biodiversity. After cessation of management practices the cover of tall grasses and forbs with larger leaves as well as of species reproducing vegetatively increases rapidly in many grasslands. They reduce light penetration to lower layers of the grasslands and restrict the development of shorter species. The dominance of tall grasses and non-removal of organic matter lead to the formation of a thick litter layer, which hinder germination and growth of seedlings. A thick litter layer in the dense grassland impedes also seed germination and seedling development

* Corresponding author. Email: ubdzwonk@cyf-kr.edu.pl

This is an Open Access digital version of the article distributed under the terms of the Creative Commons Attribution 3.0 License (creativecommons.org/licenses/by/3.0/), which permits redistribution, commercial and non-commercial, provided that the article is properly cited. of shrubs and trees, thus causing the succession to wood to proceed much slower than in more open grasslands. Such changes, usually with decrease in species diversity, have been observed in abandoned grasslands in different parts of central and western Europe[1-7].

The dynamics of structure and species composition of grasslands may depend strongly on inter-annual and multiannual fluctuations of climatic conditions. Experiments in lowland limestone grasslands have shown that species richness and plant cover significantly increased in plots receiving supplementary summer rainfall [8,9]. Long-term observations have indicated that summer rainfall is an important factor in controlling directly and indirectly species richness and composition of grassland and meadow communities [10-13]. Temperature is also an important factor affecting the composition and dynamics of some semi-natural grasslands in temperate region, and may exert either a positive or negative effect on the biomass and growth of grassland species, depending on the level of precipitation $[8,9,12,14]$ Moreover, lagged temporal responses of grassland vegetation to climatic fluctuations, especially to major climatic events, up to two or more years were observed [12,15-17]. The results of some studies indicate that the fluctuations of precipitation and temperature may affect the rate of secondary succession. Wetter conditions during summer may promote growth of perennial grasses, which tend to close the sward $[8,18]$. Thereby they can inhibit the establishment of later successional species. While severe droughts may open gaps for regeneration by causing the 
mortality of established plants. The majority of observations and experiments on the effect of the weather on the dynamics of limestone grassland vegetation cited above concerned grasslands treated in varying degree and manner. However, very little is known about the role of climatic conditions in shaping vegetation in abandoned grasslands.

Various studies revealed that plant functional traits, such as growth form, lateral expansion, plant height, leaf size and type of morphological or anatomical structure, which determine competitive ability of species and course of succession, can be used for functional analysis of vegetation dynamics in order to understand processes and predict changes in untreated grasslands $[7,19,20]$. Using plant functional groups besides species makes possible identify general tendencies in vegetation changes as well as comparison between differing communities with respect to specific processes. Based on the mentioned functional traits we analysed impact of weather on vegetation dynamics in abandoned limestone grassland during 12 years. The purpose of this study was to examine: $(\boldsymbol{i})$ how do various plant functional groups and species respond to interannual variation in precipitation and temperature, and (ii) to what extend the rate and direction of changes in abandoned grassland may depend on fluctuations in climatic conditions.

\section{Material and methods}

\section{Study area}

The study was carried out in the Skołczanka reserve (36 ha; $\left.50^{\circ} 01^{\prime} \mathrm{N}, 19^{\circ} 50^{\prime} \mathrm{E}\right)$, situated in southern Poland, some 8 $\mathrm{km}$ southwest of the center of Kraków. The reserve includes of Jurassic limestone hill elevated $275 \mathrm{~m}$ a.s.l. As late as in the 1940s and 1950s, the grassland covering most of the hill was grazed by domestic animals. After the reserve was established in 1957, trees and shrubs have begun to colonize the grassland, and the secondary woods have increased considerably in area at the expense of grassland communities. Only at the top of the hill larger patch of grassland with only scattered woody species has remained. The remnant of old grassland represents the Koelerio-Festucetum association with such characteristic species as Festuca rupicola, Koeleria macrantha and Phleum phleoides. More details of the vegetation in the reserve and direction and rate of secondary succession are given by Dzwonko and Loster [5,20,21].

\section{Data collection and analysis}

In 1992, eight permanent plots, $5 \mathrm{~m} \times 5 \mathrm{~m}$, were established systematically at $5 \mathrm{~m}$ distances in the old abandoned grassland. From 1992 to 2003, the percentage cover (at $10 \%$ estimation intervals) of vascular plant species was estimated in each plot at the end of June or in July. Over 12 years, a total of 15 tree and shrub species and 87 herbaceous and small shrub species were recorded on the study plots. The nomenclature of plant species is that used in Flora Europaea by Tutin et al. [22].

The cover of herb species with various states of four functional traits was calculated. Species were divided into five groups with various growth forms and vegetative reproduction: annuals and biennials, non-tufted perennials without runners or rhizomes, tufted perennials, perennials with short runners or rhizomes, and perennials with long runners or rhizomes. The other traits were: plant height (with four states, $<30 \mathrm{~cm}$, $30-59.9 \mathrm{~cm}, 60-100 \mathrm{~cm},>100 \mathrm{~cm}$ ), leaf area (with three states,
$<1 \mathrm{~cm}^{2}, 1-10 \mathrm{~cm}^{2},>10 \mathrm{~cm}^{2}$ ), and leaf anatomy (with two states, scleromorphic and mesomorphic; plants with other leaf anatomy were almost absent). The values and categories of these traits were determined for each species using the databases of Kleyer [23], Hodgson [24] and Klotz et al. [25].

Climatic data were obtained from the meteorological station of the Jagellonian University, situated approx. $10.5 \mathrm{~km}$ from the study grassland. Climatic data for 15 years (from 1989 to 2003) were taken into account. This enabled comparisons between weather and plant performances with time lags of up to 3 years. During mentioned period, mean annual temperatures varied from $7.1^{\circ} \mathrm{C}$ (in 1996) to $10.2^{\circ} \mathrm{C}$ (in 2000), the mean temperature of the coldest month from $-5.8^{\circ} \mathrm{C}$ (January 1997) to $3.3^{\circ} \mathrm{C}$ (January 1994), and the mean temperature of the warmest month from $17.2^{\circ} \mathrm{C}$ (July 1996) to $21.5^{\circ} \mathrm{C}$ (July 1994). Total annual precipitation varied from $448 \mathrm{~mm}$ (in 1993) to $857 \mathrm{~mm}$ (in 1997).

Relationships between cover of species of different groups and temperature and precipitation data were analysed using multiple linear regression. For every trait state, the total species cover presenting that trait state was calculated and used as dependent variable in a series of regression models with all analysed climatic variables as explanatory variables. In each model besides one climatic variable also variable time was incorporated to control long-term changes and the plots were included as dummy variables to control the variation among plots. The climatic variables considered in regression models for every trait state included mean temperatures for each month from January to December, and mean temperatures for two, three and four consecutive months beginning from January, for the one, two and three years previously. For the current year only data for period from January to July were taken into account as vegetation records were collected not later than in July. Precipitation sums were analysed for the same months and periods including also total annual precipitation.

Multiple regression analysis with forward selection procedure was applied to find a set of climatic variables that explains the greatest part of the variability in every trait state and in cover of more frequent species. In the procedure for trait states the variables time and plots were included in the model first of all and then climatic variables were incorporated by stepwise selection. Only climatic variables significantly related to a given trait state according to regression models for single climatic variables were examined. Similar procedure was applied for more frequent herbaceous species. It is for 41 species occurring during at least six years in the study plots and in at least one year in four plots. The variable time was tested first of all and if significant included in the model and then climatic variables were examined. In the case of species all climatic variables significantly related to distinguished species groups were taken into account in forward selection. Only variables explained at least $3 \%$ of variability in the cover of a particular species were included in the model.

The significance of regression coefficients was evaluated using permutation test in order to avoid assumption of normal data distribution. Problems with autocorrelation in time series were avoided by applying restricted permutations. The regression analyses were performed using program CANOCO [26] that provides permutation tests for time series. For comparison, the tests under full model and under reduced model with 999 permutations restricted to the same cyclic shifts within parallel time series were used. The former test is more liberal and the latter is more conservative. 
Results

\section{Relations between functional groups and weather}

The cover of most of the plant functional groups was significantly related to climatic conditions in the current year and in three preceding years. The same main results were obtained for both the permutation tests. In the case of more liberal test, permutation under full model, the level of significance for most response variables was at $P=0.001$ and sometimes at $P$ between 0.01 and 0.001 . However, we present results for much more conservative test, i.e. permutation under reduced model, with lover levels of significance, to be surer that they are not spurious in consequence of multiple testing. In the current year, the most effect on the dynamics of plant functional groups had the variability of rainfall in spring and early summer (Tab. 1). With the increase of precipitation in this period, the cover of most of the plant groups studied increased. Precipitation in the period from April to June had the greatest impact on the cover of the tallest plants $(>100 \mathrm{~cm})$ and on plants with the smallest and largest leaves $\left(<1 \mathrm{~cm}^{2}\right.$ and $>10$ $\mathrm{cm}^{2}$; Fig. 1). Rainfall in the period from May to June had the strongest effect on the cover of annuals and biennials, whereas that in June alone - on the cover of plants with mesomorphic leaves, with larger leaves $\left(1-10 \mathrm{~cm}^{2}\right)$, tufted perennials, and perennials with long vegetative spread. Some of the plant groups were significantly connected with precipitation only in winter and spring. This concerned tall plants $(60-100 \mathrm{~cm})$ and plants with scleromorphic leaves, whose cover was negatively correlated with precipitation in the period from December to March, and in the case of the second group - also with precipitation from November to January. The positive effect of winter precipitation, in January and February, was found only in the case of perennials with short vegetative spread.

The stepwise regression analysis revealed that the dynamics of the specified plant functional groups had a significant relationship with the precipitation in all the above mentioned periods (Tab. 2). The higher the value of the regression coefficient, the greater influence the independent variable on the cover of plant group. This analysis indicated that precipitation in spring and/or early summer in the current year had the greatest impact on variability in most of the plant groups, compared with other climatic variables. The results of the stepwise regression analysis suggest that temperature in the current year had a significant effect only on the cover of tall plants $(60-100 \mathrm{~cm})$ - which was positively correlated with the mean temperature in the period from May to July, and on the cover of plants with mesomorphic leaves - that was negatively correlated with the temperature in May.

In the case of climatic data from the previous year, the dynamics of vegetation was most strongly related to the temperature in spring and summer. According to results of stepwise regression analysis the higher temperature in the period from April to June had a positive effect on the cover of perennials with short vegetative spread, and the temperature in May and June - on the cover of the shortest plants $(<30 \mathrm{~cm})$, plants with small leaves $\left(<1 \mathrm{~cm}^{2}\right)$, and non-tufted perennials, whereas the higher temperature in August affected the cover of tall plants $(60-100 \mathrm{~cm})$. On the other hand, the lower temperature in late summer and autumn, in the periods from August to November and from September to November, was connected with a greater cover of plants with small leaves $\left(<1 \mathrm{~cm}^{2}\right)$ and scleromorphic plants, respectively. Only cover of two functional groups - plants with larger leaves $\left(1-10 \mathrm{~cm}^{2}\right)$ and non-tufted perennials, was significantly correlated with precipitation in the previous year.

According to regression models for single climatic variables with lags of two and three years the variability in the studied functional groups were significantly related to precipitation and temperature for various periods, chiefly in spring and summer (Tab. 1). However, the results of stepwise regression analysis suggest, that only some of these variables had significant effect when the impact of precipitation and temperature in the current and previous year was taken into account (Tab. 2). Only in three cases did climatic conditions with time lags of two and three years have a greater effect on the cover of species groups than the weather in the current and/or previous year. The cover of short plants $(<30 \mathrm{~cm})$ was positively correlated with the sum of precipitation in the period from May to July two years previously. The greater cover of scleromorphic plants was connected with lower precipitation in June and July, and the greater cover of annuals and biennial with higher temperature in June three years previously.

\section{Successional changes in community composition}

The results of the analyses suggest that over the period of 12 years, the vegetation of the studied grassland also changed, as a result of the successional process occurring independently of the changes connected with fluctuations in climatic conditions. During that time, the mean cover of shrub layer increased only slightly in the plots (from $6.2 \%$ to $12.9 \%$ ), and the sward was rather dense. Its mean cover varied from $76.9 \%$ to $96.9 \%$. At the same time the cover of short plants $(<30 \mathrm{~cm})$ decreased significantly, while that of tall plants $(30-100 \mathrm{~cm})$ increased (Tab. 2). In addition, the cover of plants with small leaves $\left(<1 \mathrm{~cm}^{2}\right)$ decreased, whereas the cover of plants with larger leaves and with mesomorphic leaves increased. There was a significant drop in the cover of annuals and biennial, as well as tufted perennials, while the cover of non-tufted perennials and perennials with vegetative spread increased.

\section{Response of species}

The most common species in the studied grassland can be divided into three groups: dominants (4 species) - with a maximum cover in the plots between $30 \%$ and $50 \%$, subdominants (11 species) - with a maximum cover between $10 \%$ and $30 \%$, and companions (26 species), with a cover always lower than $10 \%$. The cover of almost all analysed species depended on climatic conditions, chiefly precipitation in the current year and/or in previous years (Tab. 3). The cover of 12 species (3 dominants, 3 subdominants, and 6 companions) increased or, more rarely, decreased significantly during a 12 -year succession, irrespective of fluctuating changes connected with weather. Only 5 companion species (omitted in Tab. 3) were not considerably related to time and/or weather. Among the dominants, only the cover of Arrhenatherum elatius was unchanged throughout 12 years, although it depended significantly on precipitation in the spring and summer (April-June) of the current year and in the summer and autumn (AugustOctober) of the previous year. In the same period, the cover of Vincetoxicum hirundinaria increased significantly, whereas the cover of Festuca rupicola and Phleum phleoides, which are generally of a smaller size and have a smaller leaf area compared with the species mentioned earlier, decreased considerably. Among other species groups only the cover of Sedum acre - a very small-size succulent, decreased significantly, whereas the 
Tab. 1 Results of the multiple regression analyses for single climatic variables used to estimate of the changes in plant functional groups.

$\begin{array}{lllllllllll}\text { Current year } & P & E_{\mathrm{c}}(\%) & \text { Previous year } & P & E_{\mathrm{c}}(\%) & \text { Two years prev. } & P & E_{\mathrm{c}}(\%) & \text { Three years prev. } P & E_{\mathrm{c}}(\%)\end{array}$

\begin{tabular}{|c|c|c|c|c|c|c|c|c|c|c|c|c|}
\hline \multicolumn{13}{|c|}{ Plant height $(\mathrm{cm})$} \\
\hline$<30$ & Pr June + & $* *$ & 3.4 & T May-June + & * & 4.2 & Pr May-July + & $* *$ & 5.4 & Pr May + & $* *$ & 6.9 \\
\hline \multirow[t]{2}{*}{$(47.2-61.0)$} & Pr Jan.-Feb. + & $* *$ & 3.1 & T Sept.-Nov. - & $* *$ & 3.8 & T April - & ** & 7.2 & Pr Aug.-Sept. + & $* *$ & 5.7 \\
\hline & & & & & & & T Dec.-Jan. - & $* *$ & 6.1 & Pr June-July - & $* *$ & 5.4 \\
\hline $30-59.9$ & Pr June + & $* *$ & 4.1 & & & & T March-April - & $* *$ & 2.9 & T March-April - & * & 3.3 \\
\hline \multirow[t]{2}{*}{$(31.1-64.4)$} & Pr May-June + & $* *$ & 3.6 & & & & T March - & $*$ & 2.6 & T Feb.-May - & $* *$ & 2.6 \\
\hline & Pr April-June + & $* *$ & 3.1 & & & & & & & T March - & $*$ & 2.5 \\
\hline \multirow{3}{*}{$\begin{array}{l}60-100 \\
(5.7-13.1)\end{array}$} & Pr Dec.-March - & $* *$ & 4.6 & T Aug. + & * & 2.8 & T Oct.-Nov. + & ** & 4.4 & T April + & * & 5.0 \\
\hline & Pr March-April - & * & 2.7 & & & & T Aug.-Nov. + & * & 4.3 & T March-May + & * & 4.1 \\
\hline & T May-July + & $* *$ & 5.0 & & & & & & & & & \\
\hline \multirow{3}{*}{$\begin{array}{l}>100 \\
(16.2-31.6)\end{array}$} & Pr April-June + & $* *$ & 13.2 & Pr June-Sept. + & $* *$ & 6.9 & T Oct.-Jan. - & * & 8.6 & Pr June-July - & * & 8.9 \\
\hline & Pr June + & $* *$ & 12.3 & Pr July-Sept. + & $* *$ & 6.2 & T Nov.-Feb. - & $* *$ & 5.5 & Pr June-Aug. - & $* *$ & 8.8 \\
\hline & Pr May-June + & $* *$ & 11.9 & Pr March-June + & * & 6.0 & & & & T May-July + & $* *$ & 9.8 \\
\hline
\end{tabular}

\section{Leaf area $\left(\mathrm{cm}^{2}\right)$}

$<1$

(48.6-68.0)

Pr April-June +

9.9 T Aug.-Nov. -

Pr June +

9.2 T July-Oct. -

* $\quad 10.3$ T March-April - *

* $\quad 11.2$ Pr May +

9.6

5.8 T April $+* * \quad 8.8 \mathrm{~T}$ Teb.-March $-x_{*}+11$.

\begin{tabular}{|c|c|c|c|c|c|c|c|c|c|c|c|}
\hline $1-10$ & Pr Feb.+ & ** & 2.4 & Pr April + & $* *$ & 1.8 & Pr May-July + & * & 1.8 & & \\
\hline \multirow[t]{2}{*}{$(20.0-33.9)$} & Pr June + & $* *$ & 2.2 & Pr Jan.-Dec. + & * & 1.2 & Pr May-Aug. + & $* *$ & 1.4 & & \\
\hline & & & & & & & Pr Jan.-Feb. - & ** & 1.4 & & \\
\hline \multirow{3}{*}{$\begin{array}{l}>10 \\
(31.0-64.5)\end{array}$} & Pr April-June + & $* *$ & 10.7 & & & & & & T Feb.-March - & * & 6.5 \\
\hline & Pr June + & ** & 10.4 & & & & & & T May-July + & * & 5.7 \\
\hline & Pr May-June + & ** & 10.3 & & & & & & & & \\
\hline
\end{tabular}

\section{Leaf anatomy}

Scleromorphic

(59.7-80.4)

Pr Nov.-Jan. - $\quad$ ** $\quad 3.6$ Pr Feb. -

Pr Dec-March $-* x$

T April-May -

Mesomorphic

Pr June $+\quad$ ** $\quad 9.7$

(31.7-85.7)

Pr April-June $+\quad * * \quad 7.1$

T May - $\quad$ ** 5.0

$* * \quad 2.5$ T March-June -
$* \quad \quad 2.9$ T April -

$\star \quad 2.6$
3.2 Pr June-July - $\quad$ * $\quad 5.8$

2.8 Pr April-July - $\quad$ * $\quad 5.0$

Pr May-July - $\quad$ * $\quad 4.5$

\section{Growth forms}

Annuals and biennials

(1.5-7.0)

Pr April-June +

Non-tufted perennials

(17.4-39.2)

Tufted perennials

(50.1-74.4)

Pr June +

Pr Nov-Jan.

** $\quad 9.4$ Pr Feb. -

T April-May

* $\quad 4.1$ Pr Aug.-Sept. + $*$

* $\quad 3.3$ Pr Aug.-Oct. $+\quad * \quad 3.3$

Perennials with short veg. spread Pr Jan.-Feb.+ $\quad * * \quad 4.0$ T April-June $+\quad * \quad$ * $\quad 2.5$ T Dec.-Jan. - $\quad$ ** $\quad 2.2 \quad$ T March-April - $\quad * * \quad 3.2$

$(11.6-30.1)$

\section{Pr March-June $+\quad * \quad 3.1$ T April-May +}

Pr Jan.-March $+\quad * * \quad 2.9$

T Oct.-Jan. - $\quad$ ** $\quad$ 7.8 T March - $\quad * * \quad 5.4$

T Nov.-Jan. - $\quad$ ** $\quad 6.4$ T March-April - * $\quad$ * 5.3

T Dec.-Jan. - $\quad$ ** $\quad$ 6.3 T Jan.-March - $\quad * * \quad 4.4$

$\begin{array}{llll} & \text { Pr Jan.-March }+* * & 2.9 \\ \text { Perennials with long veg. spread } & \text { Pr June }+ & * * & \\ (9.1-28.4) & \text { Pr Feb. } & * * & 3.8 \\ & \text { Pr May-June }+ & * & 3.6\end{array}$


Only regression results for precipitation and temperature are presented. Results for variables time and plots are omitted. For each year only three climatic variables most strongly related to vegetation variables are shown. Variation ranges of mean percentage cover of species groups are given in parentheses. “+” “-” - positive and negative relationship, respectively; $E_{\mathrm{c}}$ - variability in functional groups explained by climatic variables; $\operatorname{Pr}$ - precipitation; $\mathrm{T}$ - temperature. ${ }^{\star} P<0.1 ;{ }^{\star \star} P \leq 0.05$.

cover of Festuca rubra, Euphorbia cyparissias, Veronica chamaedrys, Avenula pubescens, Medicago lupulina, Veronica spicatum, Ranunculus bulbosus and Clinopodium vulgare, all increased. Almost all of the listed subdominants and companion species, whose cover increased significantly, have mesomorphic leaves of larger sizes.

Five subdominants and companions had a greater cover with higher precipitation in spring and/or early summer of the current year, in periods from one month (June) to four months (March-June), three species - in the summer (June-September) of the previous year, and eight species - in spring and summer (mostly May-August) two or three years previously. The cover of only three species was higher coinciding with more
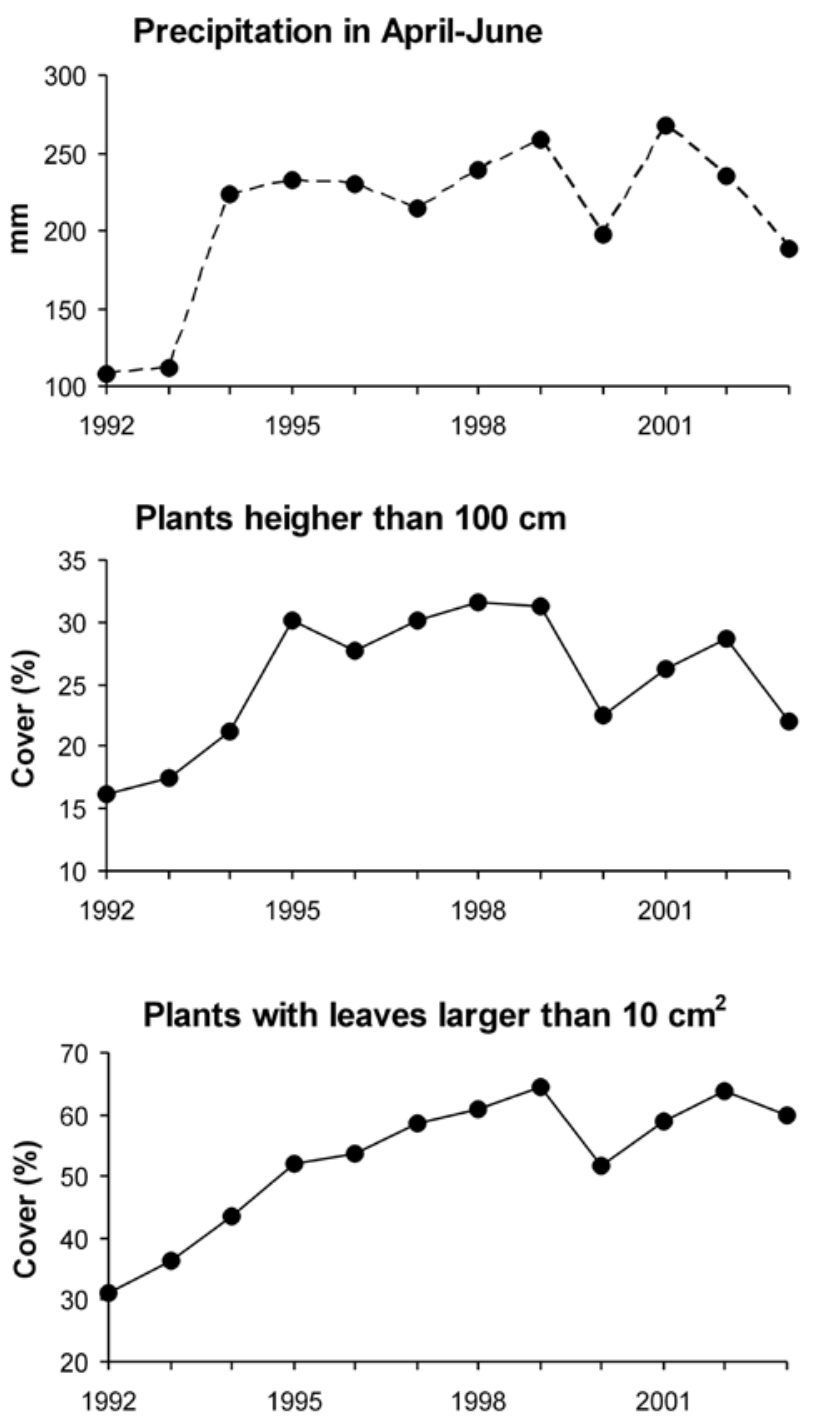

precipitation in winter (January-March) or late autumn and winter (November-February) of the current year. The increase in cover of seven species was connected with lower precipitation in various months during spring and/or summer, in one out of the four study years. However, in the case of four of these species, the higher precipitation in other years had a positive effect on their cover. The cover of 18 species under study was significantly related to the temperature in various seasons of the year, but in only seven of these species was no parallel effect of precipitation found. Higher mean temperatures in spring and/or summer, and sometimes even in winter and spring, as well as in autumn, in the period from one month (May, June, August) to three or four months with lags of 0, 1, 2 and

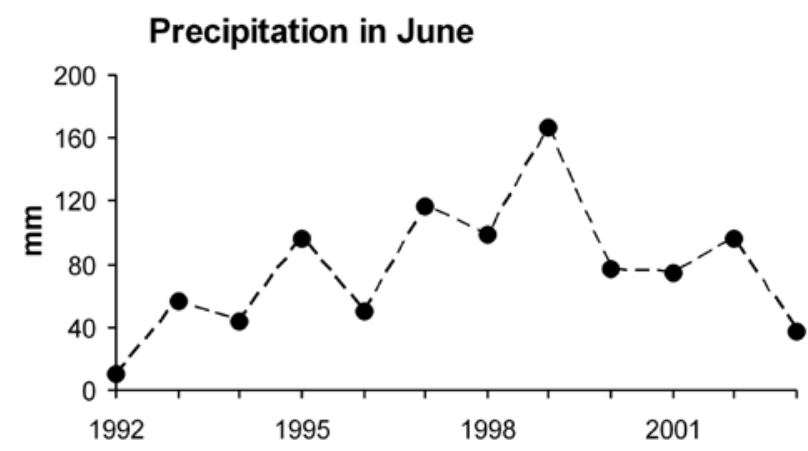

Plants with mesomorphic leaves

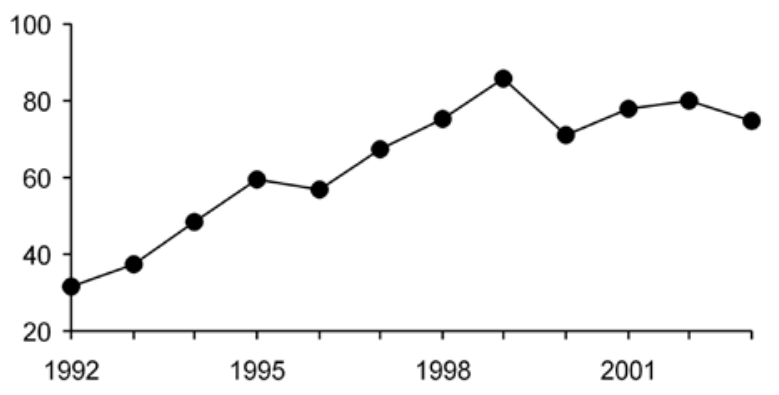

Tufted perennials

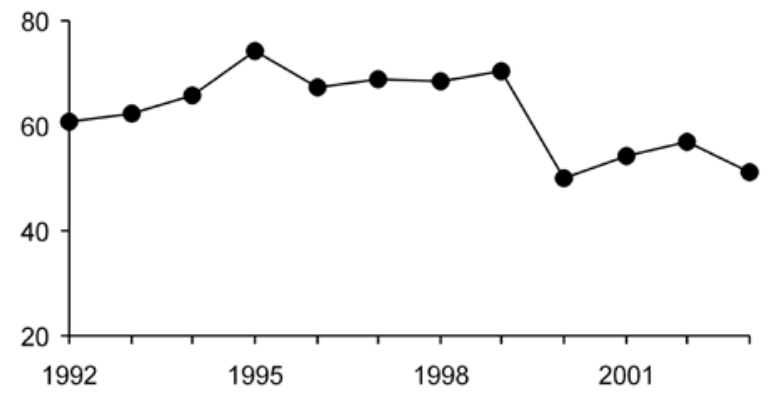

Fig. 1 Precipitation sums in the period from April to June and in June, and mean cover of different plant functional groups in the plots, during 1992-2003. 
Tab. 2 Results of the stepwise multiple regression analyses used to estimate of the changes in plant functional groups in relation to precipitation, temperature and time.

\begin{tabular}{|c|c|c|c|c|c|c|c|c|}
\hline & Current year & Previous year & Two years previously & Three years previously & $E_{c}(\%)$ & $\beta_{\mathrm{t}}$ & $E_{\mathrm{t}}(\%)$ & $R^{2}(\%)$ \\
\hline \multicolumn{9}{|l|}{ Plant height (cm) } \\
\hline$<30$ & & T May-June $+0.16^{* *}$ & Pr May-July $+0.26^{* *}$ & Pr June-July $-0.11^{\star}$ & 9.3 & $-0.27^{\star *}$ & 1.7 & 67.2 \\
\hline $30-59.9$ & Pr May-June $+0.19^{* *}$ & & T March-April $-0.12^{*}$ & & 5.0 & $+0.31^{* *}$ & 6.0 & 73.6 \\
\hline \multirow[t]{2}{*}{$60-100$} & T May-July $+0.19^{* *}$ & T Aug. $+0.11^{\star \star}$ & & & 8.7 & $+0.27^{\star *}$ & 4.4 & 48.6 \\
\hline & Pr Dec.-March $-0.16^{* *}$ & & & & & & & \\
\hline$>100$ & Pr April-June $+0.34^{\star *}$ & & & T May-July $+0.27^{\star *}$ & 16.6 & -0.16 & 1.4 & 56.8 \\
\hline \multicolumn{9}{|l|}{ Leaf area $\left(\mathrm{cm}^{2}\right)$} \\
\hline \multirow[t]{2}{*}{$<1$} & Pr April-June $+0.25^{*}$ & T May-June $+0.13^{*}$ & T March-April $-0.14^{* *}$ & & 19.0 & $-0.18^{* *}$ & 1.3 & 43.8 \\
\hline & & T Aug.-Nov. $-0.18^{* *}$ & & & & & & \\
\hline $1-10$ & Pr June $+0.12^{\star *}$ & Pr April $+0.08^{* *}$ & & & 2.7 & $+0.24^{* *}$ & 5.1 & 67.1 \\
\hline$>10$ & Pr April-June $+0.39^{* *}$ & & & & 10.7 & $+0.38^{* *}$ & 9.1 & 63.1 \\
\hline \multicolumn{9}{|l|}{ Leaf anatomy } \\
\hline Scleromorphic & Pr Dec.-March $-0.10^{* *}$ & T Sept.-Nov. $-0.10^{* *}$ & & Pr June-July $-0.20^{*}$ & 7.7 & -0.01 & 0.0 & 63.2 \\
\hline \multirow[t]{2}{*}{ Mesomorphic } & Pr June $+0.22^{\star \star}$ & & T Oct.-Jan. $-0.10^{*}$ & & 11.1 & $+0.63^{* *}$ & 17.6 & 78.0 \\
\hline & T May $-0.11^{\star *}$ & & & & & & & \\
\hline \multicolumn{9}{|l|}{ Growth forms } \\
\hline Annuals and biennials & Pr May-June $+0.28^{* *}$ & & & T June $+0.64^{\star *}$ & 36.8 & $-0.56^{* *}$ & 16.9 & 45.4 \\
\hline \multirow[t]{2}{*}{ Non-tufted perennials } & & Pr Jan.-Feb. $-0.15^{\star}$ & & & 2.1 & $+0.57^{* *}$ & 9.1 & 64.4 \\
\hline & & T May-June $+0.11^{* *}$ & & & & & & \\
\hline Tufted perennials & Pr June $+0.27^{* *}$ & & & Pr June-Aug. $-0.22^{* *}$ & 13.3 & $-0.28^{* *}$ & 6.1 & 49.9 \\
\hline \multirow[t]{2}{*}{ Perennials with short veg. spread } & Pr Jan.-Feb. $+0.15^{\star \star}$ & T April-June $+0.12^{\star *}$ & & & 5.6 & $+0.32^{* *}$ & 5.8 & 63.9 \\
\hline & Pr March-June $+0.09^{* *}$ & & & & & & & \\
\hline Perennials with long veg.spread & Pr June $+0.23^{\star \star}$ & & Pr Jan.-Dec. $+0.17^{*}$ & & 6.4 & $+0.28^{* *}$ & 4.3 & 72.3 \\
\hline
\end{tabular}

Values are standardized partial regression coefficients. $\beta_{\mathrm{t}}$ - regression coefficient for variable time; $E_{\mathrm{c}}$ - variability in plant functional groups explained by climatic variables; $E_{\mathrm{t}}$ - variability explained by time; $\operatorname{Pr}$ - precipitation; $\mathrm{T}$ - temperature. ${ }^{\star} P<0.1 ;{ }^{* *} P<0.05$.

3 years had a positive effect on the cover of 11 subdominants and companion species. By contrast, the cover of eight species was negatively correlated with the temperature in spring and/ or summer, or also summer and/or autumn in the current year or in the previous three years.

\section{Discussion}

The results of analyses showed that during the study period the dynamics of the observed grassland was strongly influenced by both successional processes and inter-annual fluctuations of climatic conditions with a delay from 0 to 3 years. The fluctuations in precipitation and temperature explained from $2.1 \%$ to $36.8 \%$ of the variation in the cover of various plant functional groups, whereas the variable time, assuming that climatic conditions were stable, accounted for from 0 to $17.6 \%$ of the variation in the cover of these groups. During 12 years, the cover of annuals and biennials, tufted perennials, short plants $(<30 \mathrm{~cm})$ and plants with small leaves decreased significantly. On the other hand, the cover of taller plants (30-100 cm), plants with larger leaves $\left(>1 \mathrm{~cm}^{2}\right)$ and, above all, plants with mesomorphic leaves and with vegetative spread, as well as non-tufted perennials, increased considerably. Various observations and experiments proved that the changes in the proportions of plants with these traits are characteristic for different successional series, including also abandoned grasslands $[2,3,7,27,28]$. The species of larger size, or taller and with larger leaves, have the advantage over small species in the competition for light $[29,30]$, whereas the species with extended vegetative spread have a greater chance of penetrating into more closed vegetation. 
Tab. 3 Results of the stepwise multiple regression analyses used to estimate of the changes in species cover in relation to time, precipitation and temperature.

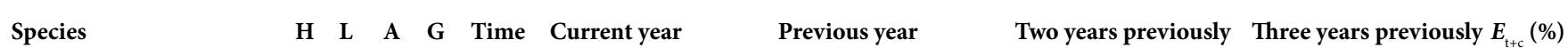

\section{Dominants}

Arrhenatherum elatius $\quad 4 \quad 3 \quad$ M Tp NS Pr April-June $+0.43^{* *}$ Pr Aug.-Oct. $+0.20^{\star *}$

wo years previously Three years previously $E_{t+c}(\%)$

Vincetoxicum hirundinaria $2 \quad 3 \quad \mathrm{~S} \quad \mathrm{~Np}+0.39^{*}$

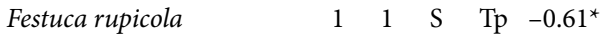

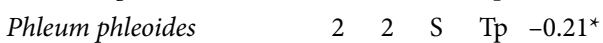

T Aug.-Nov. $-0.20^{* *}$

\section{Subdominants}

Galium mollugo

Galium verum

Companions

\begin{tabular}{|c|c|c|c|c|c|c|}
\hline Hypericum perforatum & 2 & 2 & $S$ & Ps & NS & Pr May-June $+0.32^{\star *}$ \\
\hline & & & & & & T April-May $-0.20^{\star *}$ \\
\hline Poa compressa & 2 & 1 & $\mathrm{~S}$ & $\mathrm{Pl}$ & NS & Pr Nov.-Feb. $+0.19^{* *}$ \\
\hline Anthoxantum odoratum & 1 & 2 & M & $\mathrm{Tp}$ & NS & Pr May-June $-0.23^{\star}$ \\
\hline Sanguisorba minor & 1 & 3 & $S$ & $\mathrm{~Np}$ & NS & Pr April-June $-0.16^{*}$ \\
\hline Potentilla cinerea & 1 & 2 & $S$ & Ps & NS & T May $+0.20^{* *}$ \\
\hline Taraxacum officinale & 1 & 3 & M & $\mathrm{Np}$ & NS & \\
\hline Dianthus carthusianorum & 2 & 2 & $\mathrm{~S}$ & $\mathrm{~Np}$ & NS & \\
\hline Vicia hirsuta & 1 & 2 & M & An & NS & \\
\hline Arenaria serpyllifolia & 1 & 1 & $\mathrm{~S}$ & An & NS & \\
\hline Cerastium arvense & 1 & 1 & $S$ & Ps & NS & \\
\hline Trifolium aureum & 1 & 2 & S & An & NS & \\
\hline Trifolium arvense & 1 & 1 & $S$ & An & NS & \\
\hline Achillea millefolium & 2 & 2 & S & $\mathrm{Pl}$ & NS & \\
\hline Carex caryophyllea & 1 & 2 & $S$ & Ps & NS & \\
\hline Trifolium campestre & 1 & 2 & M & An & NS & \\
\hline Avenula pubescens & 3 & 2 & M & $\mathrm{Pl}$ & $+0.63^{*}$ & Pr Nov.-Feb. $+0.25^{\star *}$ \\
\hline Medicago lupulina & 1 & 2 & M & An & $+0.29^{\star}$ & Pr June $+0.20^{* *}$ \\
\hline Veronica spicata & 2 & 2 & S & $\mathrm{Np}$ & $+0.25^{\star}$ & Pr March-June $+0.24^{*}$ \\
\hline Ranunculus bulbosus & 1 & 2 & M & $\mathrm{Np}$ & $+0.29^{*}$ & \\
\hline Clinopodium vulgare & 2 & 2 & M & $\mathrm{Pl}$ & $+0.40^{*}$ & \\
\hline Sedum acre & 1 & 1 & $\mathrm{Su}$ & Ps & $-0.10^{\star}$ & T May-July $0.20^{\star \star}$ \\
\hline
\end{tabular}

Pr May-July $-0.26^{\star *}$

T May-June $+0.21^{*}$

Pr May-Aug. +0.26*

Pr Jan.-Dec. $+0.19^{* *}$

T April-June $+0.31^{* *}$

Pr June-Aug. $+0.37^{\star *}$

Pr Jan.-Dec. $-0.18^{\star}$

Pr June-Sept. $-0.28^{\star}$

Pr Aug.-Sept. $+0.21^{\star *} \quad 35.6$

T June-Aug. $+0.70^{\star *}$

Pr May-Aug. $+0.42^{\star *}$

Pr May-Aug. $+0.36^{*}$

T Feb.-May $+0.39^{*}$

Pr June-July $-0.41^{* *}$

T Aug. $+0.20^{* *} \quad$ Pr April $-0.22^{* *}$

T April $-0.19^{* *}$

T Aug.-Nov. $+0.28^{\star *}$

T June-Aug. $+0.22^{* *}$

Values are standardized partial regression coefficients. Plant height (H): $1-<30 \mathrm{~cm} ; 2-30-59.9 \mathrm{~cm} ; 3-60-100 \mathrm{~cm} ; 4->100 \mathrm{~cm}$. Leaf area (L): $1-<1 \mathrm{~cm}^{2} ; 2-1-10 \mathrm{~cm}^{2} ; 3->10 \mathrm{~cm}^{2}$. Leaf anatomy (A): M - mesomorphic; S - scleromorphic; Su - succulent. Growth form and vegetative reproduction $(\mathrm{G})$ : An - annuals and biennials; $\mathrm{Np}$ - non-tufted perennials; $\mathrm{Tp}$ - tufted perennials; $\mathrm{Pl}$ - perennials with long vegetative spread; Ps - perennials with short vegetative spread. $E_{\mathrm{t}+\mathrm{c}}$ express variability in species cover explained by time and climatic variables; $\mathrm{Pr}$ - $\mathrm{precipitation}$; $\mathrm{T}$ - temperature. ${ }^{\star} P<0.1 ;{ }^{*} P<0.05$. 
Our observations and analyses indicate that from among climatic variables the greatest effect on the dynamics of the majority of plant functional groups had precipitation in spring and early summer, particularly in the current year. The majority of plant groups were affected by the temperatures in spring and early summer in the previous years, although, their effects were lower than that of precipitation in the current year, except for annuals and biennials. Therefore, in the case of the study grassland water was more limiting than temperature. This is consistent with observations of various authors $[10,11,15,17,31,32]$, who proved that the levels of precipitation in spring and summer has a significant impact on species composition and yield of grasslands, and that extreme droughts could be the reason for sudden and notable changes in the structure and composition of communities. Experimental studies also indicate the enormous impact of summer rainfall and summer drought upon the species richness and floristic composition of various types of grasslands in the temperate climatic zone $[8,18,33-35]$. The cited studies show that higher precipitation in spring and summer promote the domination of perennial grasses, increase their productivity and lead to the formation of a compact, closed sward structure which can lead to decreased frequency and cover of other species, particularly annuals and other short-lived plants. Summer droughts bring about the reverse effects: reduced productivity of dominants, opening up gaps in the sward and an increase in abundance of short-lived plants.

Some of detailed observations and experiments imply that higher temperature in winter and spring may have positive or negative effect on the biomass and growth rate of different grassland species, depending on precipitation. According to Dunnett et al. [12], dry and warm springs and summers promote those species that are adapted to environmental stress or disturbance (stress-tolerators, ruderals and competitive ruderals, sensu Grime), whereas species adapted to more productive conditions (competitors and stress-tolerant competitors) are retarded; these are promoted following a wet growing season. The experiments in limestone grasslands showed that, the higher temperature in winter and spring coupled with summer drought exerted a particularly strong negative impact on biomass and plant cover $[8,9]$. It may be expected that in the study area such climatic conditions may occur more often in future, because in the last century a gradual increase in the mean temperatures has been observed in Kraków in all months, at a rate from $1.02^{\circ} \mathrm{C}$ per 100 years in July, to $2.0^{\circ} \mathrm{C}$ in February and April. During that time, the mean annual temperature increased by $1.51^{\circ} \mathrm{C}$, and since 1975 , the winters have been particularly mild [36]. Such a remarkable increase in temperature can only partly be attributed to urban growth, this is testimony first of all to progressive warming of the climate, most notable in winter. As opposed to temperature, the annual sum of precipitation has changed in the last 100 years in a fluctuating manner. Thus, in the years 1973-1995 precipitation was lower, whereas in the years 1996-2005 - it was higher than the mean for the entire century [37]. During 12 years of observations, in rather dry period between 1992 and 1995, the mean sum of precipitation from May to July was $167 \mathrm{~mm}$. In a very wet year 1997, the precipitation in these months reached $479 \mathrm{~mm}$, while between the years 2000 and 2003 it was $299 \mathrm{~mm}$. Our results suggest that this temporal variability of precipitation had a substantial effect on the dynamics of many plant functional groups in the studied grassland.
Long-term observations of the dynamics of various grassland communities $[10,12,14]$ and experiments $[8,9,18,35]$ pointed out, that climatic conditions could also have a strong indirect effect through interspecific competition on the species composition and temporal changes of vegetation in grasslands. The positive feedback, with climatic conditions favouring stronger competitors, may enhance the effect of climatic fluctuations and perturbations. Precipitation can affect competitive interactions between species selectively stimulating their growth and morphological development. Fast-growing plants and those attaining larger sizes with higher rainfall can be better competitors for light as well as for soil resources. The cited studies suggest that the influences of climate are enhanced most by the interspecific competition in conditions of high productivity, on rich soils, where competition for light is most intensive. Experiments showed that the periods of drought are best survived generally by perennial deep-rooting species [18]. Such species is Arrhenatherum elatius, a principal dominant in the studied grassland throughout the period of observation, which represents the functional groups of tallest plants $(>100$ $\mathrm{cm})$ and with greatest leaf area $\left(>10 \mathrm{~cm}^{2}\right)$. Its cover was strongly positively correlated with precipitation in the spring and early summer of the current year and in the previous summer. Higher precipitation in spring and/or summer of the current year, or in one of two previous years, had also a significant positive effect on the cover of such subdominants with vegetative spread as: Galium mollugo, G. verum, Agrostis capillaris, Poa pratensis and Veronica chamaedrys, and subdominants with a large leaf area such as Coronilla varia and Plantago lanceolata. It may thus be supposed, that higher precipitation was an important factor enhancing the competitive advantage of the above-listed species, over such species as: Festuca rupicola and Phleum phleoides - initially dominating or co-dominating with Arrhenatherum elatius, but whose cover decreased markedly during the 12 years. The abundance of these two species was not positively related to precipitation, unlike their competitors. They also lack the mentioned morphological traits that give their competitors the advantage, particularly with higher precipitation.

Our studies indicate that the fluctuations in climatic conditions, chiefly precipitation, have a significant effect on both the composition and structure of vegetation and the rate of secondary succession in abandoned grasslands. It can be expected that during longer drier periods, the cover of tall grasses and perennials with broad leaves would decrease accelerating succession, because the grassland would be less compact and its colonisation by later successional species, including shrubs and trees, could be easier. The rate of succession will be much slower in wet periods when the grassland vegetation is more compact with a closed structure, owing to strong domination of tall and much branched perennial species. It explains the lack of shrub and tree seedlings in the studied grassland, in the period of observation, as well as the slow succession towards shrub and woodland communities, despite the presence of woods in the close vicinity. In this period, evident fluctuations in the climate were observed, but no one sustained period of severe drought.

\section{Acknowledgements}

We would like to thank S. Gawroński for assistance with field work. 


\section{References}

1. Willems JH. Species composition and above ground phytomass in chalk grassland with different management. Vegetatio. 1983;52:171-180. http://dx.doi.org/10.1007/ BF00044994

2. Ward LK, Jennings RD. Succession of disturbed and undisturbed chalk grassland at Aston Rowant National Nature Reserve: dynamics of species changes. J Appl Ecol. 1990;27(3):897-912. http://dx.doi.org/10.2307/2404385

3. Willems JH, Peet RK, Bik L. Changes in chalk-grassland structure and species richness resulting from selective nutrient additions. J Veg Sci. 1993;4(2):203-212. http:// dx.doi.org/10.2307/3236106

4. Mitchley J, Willems JH. Vertical canopy structure of Dutch chalk grasslands in relation to their management. Vegetatio. 1995;117(1):17-27. http://dx.doi.org/10.1007/BF00033256

5. Dzwonko Z, Loster S. Dynamics of species richness and composition in a limestone grassland restored after tree cutting. J Veg Sci. 1998;9(3):387-394. http://dx.doi. org/10.2307/3237103

6. Dzwonko Z, Loster S. Changes in plant species composition in abandoned and restored limestone grasslands - the effects of tree and shrub cutting. Acta Soc Bot Pol. 2008;77:67-75.

7. Kahmen S, Poschlod P. Plant functional trait responses to grassland succession over 25 years. J Veg Sci. 2004;15(1):2132. http://dx.doi.org/10.1111/j.1654-1103.2004.tb02233.x

8. Sternberg M, Brown VK, Masters GJ, Clarke IP. Plant community dynamics in a calcareous grassland under climate change manipulations. Plant Ecol. 1999;143(1):29-37. http://dx.doi.org/10.1023/A:1009812024996

9. Grime JP, Brown VK, Thompson K, Masters GJ, Hillier SH, Clarke IP, et al. The response of two contrasting limestone grasslands to simulated climate change. Science. 2000;289(5480):762-765. http://dx.doi.org/10.1126/ science.289.5480.762

10. Silvertown J, Dodd ME, McConway K, Potts J, Crawley M. Rainfall, biomass variation, and community composition in the Park Grass Experiment. Ecology. 1994;75(8):2430-2437. http://dx.doi.org/10.2307/1940896

11. Rosén E. Periodic droughts and long-term dynamics of alvar grassland vegetation on Öland, Sweden. Folia Geobot Phytotax. 1995;30:131-140. http://dx.doi.org/10.1007/ BF02812093

12. Dunnett NP, Willis AJ, Hunt R, Grime JP. A 38-year study of relations between weather and vegetation dynamics in road verges near Bibury, Gloucestershire. J Ecol. 1998;86(4):610623. http://dx.doi.org/10.1046/j.1365-2745.1998.00297.x

13. Ingerpuu N, Kupper T. Response of calcareous grassland vegetation to mowing and fluctuating weather conditions. J Veg Sci. 2007;18(1):141-146. http://dx.doi. org/10.1111/j.1654-1103.2007.tb02524.x

14. Herben T, Krahulec F, Hadincova V, Pechackova S. Climatic variability and grassland community composition over 10 years: separating effects on module biomass and number of modules. Funct Ecol. 1995;9(5):767-773. http://dx.doi. org/10.2307/2390250

15. Stampfli A. Species composition and standing crop variation in an unfertilized meadow and its relationship to climatic variability during six years. Folia Geobot Phytotax. 1995;30(2):117-130. http://dx.doi.org/10.1007/BF02812092

16. Haddad NM, Tilman D, Knops JMH. Long-term oscillations in grassland productivity induced by drought. Ecol Lett. 2002;5(1):110-120. http://dx.doi. org/10.1046/j.1461-0248.2002.00293.x

17. Stampfli A, Zeiter M. Plant regeneration directs changes in grassland composition after extreme drought: a 13-year study in southern Switzerland. J Ecol. 2004;92(4):568-576. http://dx.doi.org/10.1111/j.0022-0477.2004.00900.x

18. Morecroft MD, Masters GJ, Brown VK, Clarke IP, Taylor ME, Whitehouse AT. Changing precipitation patterns alter plant community dynamics and succession in an ex-arable grassland. Funct Ecol. 2004;18(5):648-655. http://dx.doi. org/10.1111/j.0269-8463.2004.00896.x

19. Prach K, Pyšek P, Šmilauer P. Changes in species traits during succession: a search for pattern. Oikos. 1997;79(1):201205. http://dx.doi.org/10.2307/3546109

20. Dzwonko Z, Loster S. A functional analysis of vegetation dynamics in abandoned and restored limestone grasslands. J Veg Sci. 2007;18(2):203-212. http://dx.doi. org/10.1111/j.1654-1103.2007.tb02531.x

21. Dzwonko Z, Loster S. Vegetation differentiation and secondary succession on a limestone hill in southern Poland. J Veg Sci. 1990;1(5):615-622. http://dx.doi. org/10.2307/3235567

22. Tutin TG, Heywood VH, Burges NA, Moore DM, Valentine $\mathrm{DH}$, Walters SM, et al., editors. Flora Europaea. Cambridge: Cambridge University Press; 1964-1980. (vol 1-5).

23. Kleyer M. Biological traits of vascular plants. A database. Stuttgart: Arbeitsberichte Institut für Landschaftsplanung und Ökologie, Universität Stuttgart; 1995. (vol 2).

24. Hodgson J, Grime JP, Hunt R, Thompson K. The electronic comparative plant ecology. London: Chapman and Hall; 1995.

25. Klotz S, Kühn I, Durka W. BIOLFLOR - eine Datenbank mit biologisch-ökologischen Merkmalen zur Flora von Deutschland. Bonn: Bundesamt fur Naturschutz; 2002.

26. ter Braak CJF, Šmilauer P. CANOCO reference manual and user's guide to Canoco for Windows: software for canonical community ordination (version 4). Ithaca NY: Microcomputer Power; 1998.

27. Prach K, Pyšek P. Clonal plants - what is their role in succession? Folia Geobot Phytotax. 1994;29(2):307-320. http:// dx.doi.org/10.1007/BF02803803

28. Jensen K, Schrautzer J. Consequences of abandonment for a regional fen flora and mechanisms of successional change. Appl Veg Sci. 1999;2(1):79-88. http://dx.doi. org/10.2307/1478884

29. Gaudet CL, Keddy PA. A comparative approach to predicting competitive ability from plant traits. Nature. 1988;334(6179):242-243. http://dx.doi. org/10.1038/334242a0

30. Keddy P, Nielsen K, Weiher E, Lawson R. Relative competitive performance of 63 species of terrestrial herbaceous plants. J Veg Sci. 2002;13(1):5-16. http://dx.doi. org/10.1111/j.1654-1103.2002.tb02018.x

31. Buckland SM, Grime JP, Hodgson JG, Thompson K. A comparison of plant responses to the extreme drought of 1995 in northern England. J Ecol. 1997;85(6):875-882. http://dx.doi.org/10.2307/2960608

32. Morecroft MD, Bealey CE, Howells O, Rennie S, Woiwod IP. Effects of drought on contrasting insect and plant species in the UK in the mid-1990s. Global Ecol Biogeogr. 2002;11(1):7-22. http://dx.doi. org/10.1046/j.1466-822X.2002.00174.X 
33. van der Maarel E. Fluctuations in a coastal dune grassland due to fluctuations in rainfall: experimental evidence. Vegetatio. 1981;47:259-265. http://dx.doi.org/10.1007/ BF00118403

34. Buckland SM, Thompson K, Hodgson JG, Grime JP. Grassland invasions: effects of manipulations of climate and management. J Appl Ecol. 2001;38(2):301-309. http:// dx.doi.org/10.1046/j.1365-2664.2001.00603.x

35. Kammer PM. Developmental responses of subdominant grassland species to current weather conditions and their relevance for annual vegetation changes. Folia Geobot. 2002;37(2):185-204. http://dx.doi.org/10.1007/BF02804231

36. Piotrowicz K. Temperatura powietrza. In: Matuszko D, editor. Klimat Krakowa w XX wieku. Kraków: Jagiellonian University Institute of Geography and Spatial Management; 2007. p. 99-112.

37. Twardosz R. Opady atmosferyczne. In: Matuszko D, editor. Klimat Krakowa w XX wieku. Kraków: Jagiellonian University Institute of Geography and Spatial Management; 2007. p. 127-138. 